\title{
N-(Thieno[2,3-b]Pyridin-3-yl)Cyanoacetamides: Synthesis and Cyclizations ${ }^{\dagger}$
}

\author{
Tatyana S. Didikina ${ }^{1}$, Elena A. Chigorina ${ }^{2}$, Darya Yu. Lukina ${ }^{1}$, Alexander V. Bespalov ${ }^{1}$, \\ Victor V. Dotsenko ${ }^{1,3, *}$ and Nicolai A. Aksenov ${ }^{3}$ \\ 1 Kuban State University, 149 Stavropolskaya str, Krasnodar 350040, Russia; \\ 2 The Federal State Unitary Enterprise "Institute of Chemical Reagents and High Purity Chemical \\ Substances" of National Research Centre "Kurchatov Institute", 3 Bogorodsky Val, Moscow 107076, \\ Russia; \\ 3 Department of Chemistry, North Caucasus Federal University, 1a Pushkin St., 355009 Stavropol, Russia; \\ * Correspondence: victor_dotsenko@bigmir.net \\ + Presented at the 24th International Electronic Conference on Synthetic Organic Chemistry, 15 November- \\ 15 December 2020; Available online: https://ecsoc-24.sciforum.net/.
}

\begin{abstract}
A series of N-(thieno[2,3-b]pyridin-3-yl)cyanoacetamides were prepared by reaction of 3aminothieno[2,3-b]pyridines with 1-cyanoacetyl-3,5-dimethytlpyrazole. Upon treatment with alkali, N-(2-alkoxycarbonylthieno[2,3-b]pyridin-3-yl)cyanoacetamides undergo Camps-type cyclization to give dipyridothiophenes. The relative stability of their tautomers was estimated by quantum chemical calculations. In contrast, cyclization of 3-(2-cyanoacetamido)thieno[2,3b]pyridine-2-carboxamides lead to the formation of pyrido[ $\left[3^{\prime}, 2^{\prime}: 4,5\right]$ thieno[3,2-d]pyrimidines.
\end{abstract}

Keywords: heterocyclization; Camps reaction; thienopyridines; cyanoacetylation

\section{Introduction}

Cyanoacetamides belong to the most popular building blocks in organic synthesis (for reviews, see [1-6]). A number of cyanoacetylation reactions are known and plenty of methods have been reported. The most efficient methods include direct cyanoacetylation of molecules using acylating agents such as cyanoacetyl chloride, cyanoacetic acid + dimethylaminopyridine + DCC $\left(\mathrm{N}, \mathrm{N}^{\prime}-\right.$ dicyclohexylcarbo-dimide), cyanoacetic acid + acetic anhydride [4], and 1-(cyanoacetyl)-3,5dimethylpyrazole 1 [7]. 1-(Cyanoacetyl)-3,5-dimethylpyrazole $\mathbf{1}$ is very cheap, handy and preparatively easily accessible from acetylacetone and cyanoacethydrazide. It was suggested as a better alternative to most of the cyanoacetylating agents in reactions with nitrogen nucleophiles and for various heterocyclization processes [8-12]. Pyrazole 1 reacts with a variety of amines, including heterocyclic amines [7]. However, the reactions with 3-aminothieno[2,3-b]pyridines have not been reported so far prior to our studies. 3-Aminothieno[2,3-b]pyridines bear privileged thienopyridine scaffold and belong to a popular class of compounds with a very broad spectrum of biological activity [13-15]. The chemistry of 3-aminothieno[2,3-b]pyridines have been reviewed [16-20].

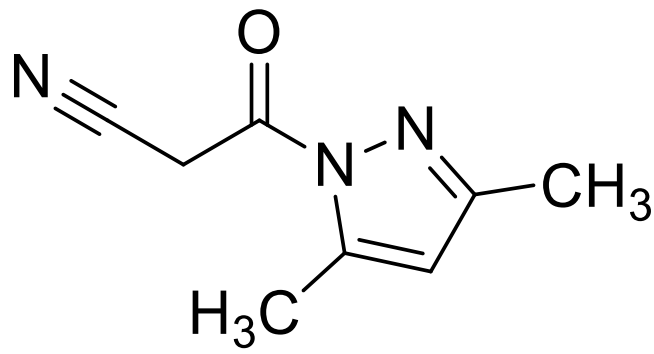


Figure 1. The structure of 1-(cyanoacetyl)-3,5-dimethylpyrazole 1.

\section{Results and Discussion}

We found that thienopyridines 2 readily reacted with 1-(cyanoacetyl)-3,5-dimethylpyrazole 1 to give new substituted cyanoacetamides 3 in good yields (Scheme 1).<smiles>Cc1cc(C)n(C(=O)CC#N)n1</smiles><smiles>[R]c1nc2sc(C(=O)OCC)c(N)c2c([R])c1[R]</smiles><smiles></smiles>

Scheme 1. Reaction of cyanoacetylpyrazole 1 with thienopyridines 2 .

Taking into account the synthetic potential of cyanoacetamides $[1,2,4]$, we decided to study reactions of 3 with 2-(arylmethylidene)malononitriles 4 . In general, cyanoacetamides are known to react with arylmethylidene malononitriles 4 to afford pyridines 5 (Scheme 2) [1,4].<smiles>[R]NC(=O)CC[N+]#N</smiles>

Scheme 2. Reaction of cyanoacetamides with arylmethylidene malononitriles 4 .

We studied the reaction of 3-(cyanoacetylamino)thienopyridines 3 with arylmethylidene malononitriles 4. Regardless of the base catalyst used (morpholine or potassium hydroxide), compounds 3 reacted with 4 in a non-selective manner to give mixtures of compounds 8-12 at different ratios, which we failed to separate (Scheme 3). The products were identified by HPLC/MS and ${ }^{1} \mathrm{H}$ NMR. Compound 10 was formed via competing intramolecular Camps-type cyclization of the starting thienopyridine substrate (Scheme 3).<smiles>CCOC(=O)c1sc2nc(C)cc(C)c2c1NC(=O)CC#N</smiles>

Scheme 3. Reaction of cyanoacetamides 3 with arylmethylidene malononitriles 4 . 
Compound 10 can exist as a few tautomers 10A-10D (Fig.1). Since it is hard to determine unambiguously the tautomer structure on the basis of NMR and IR data, the relative stability of tautomers was estimated by quantum chemical calculations.

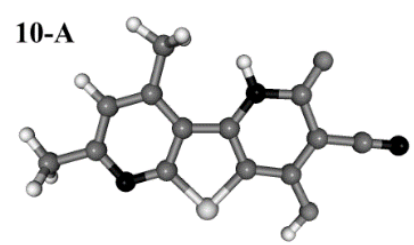<smiles>Cc1cc(C)c2c(n1)sc1c(O)c(C#N)c(=O)[nH]c12</smiles>

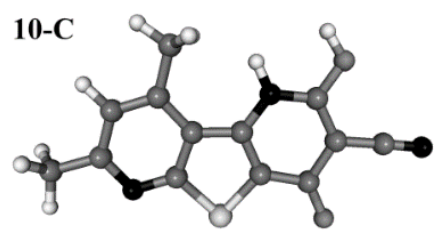<smiles>Cc1cc(C)c2c(n1)sc1c(=O)c(C#N)c(O)[nH]c12</smiles>

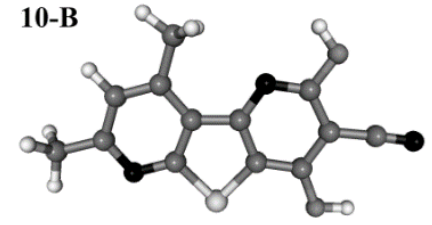<smiles>Cc1cc(C)c2c(n1)sc1c(O)c(C#N)c(O)nc12</smiles>

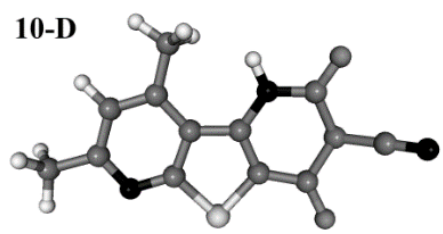<smiles>Cc1cc(C)c2c3c(sc2n1)C(=O)C(C#N)C(=O)N3</smiles>

Figure 1. Suggested tautomers for structure 10.

The calculations were performed using density functional theory with the B3LYP hybrid functional (Becke exchange functional and Lee-Yang-Parr correlation functional) and 6-31G(d,p) split-valence basis set using GAMESS software package. The obtained structures were visualized using Molekel. The ground state energies were calculated with preliminary geometry optimization with a similar basis set. Nonspecific solvation of tautomers in DMSO was taken into account in terms of the conducting polarizable continuum model (CPCM). The most stable tautomer in the gas phase is $\mathbf{1 0 B}$, and the energy of tautomer $\mathbf{1 0 A}$ is higher by $25.8 \mathrm{~kJ} / \mathrm{mol}$. Noteworthy that different results were obtained by PCM for DMSO. In this case, the most stable was tautomer $10 \mathrm{~A}$, though the energy difference between $10 \mathrm{~A}$ and $10 \mathrm{~B}$ was as small as $5.2 \mathrm{~kJ} / \mathrm{mol}$. These results allowed us to presume that compound 10 in the crystalline state has structure 10B which can be converted to tautomer $10 \mathrm{~A}$ upon dissolution in DMSO, since the latter is solvated more effectively. The strongest solvation by DMSO was predicted for tautomer 10C; however, its energy still remains relatively high (the difference is $20.2 \mathrm{~kJ} / \mathrm{mol}$ relative to $\mathbf{1 0 A}$ ). Structure $10 \mathrm{D}$ is the least favorable both in the gas phase and in DMSO solution and seems therefore hardly probable.

Finally, we studied the reactions of thienopyridine-2-carboxamides 13 with 1-(cyanoacetyl)-3,5dimethylpyrazole $\mathbf{1}$. As for thienipyridines 2 , the products were corresponding cyanoacetamides 14.However, the cyclization of $\mathbf{1 3}$ proceeds in quite different way and afford pyridothienopyrimidines 15 . 
<smiles>Cc1cc(C)n(C(=O)CC#N)n1</smiles><smiles>[R]c1nc2sc(C(N)=O)c(N)c2c([R])c1[R]</smiles><smiles>[R]c1nc2sc(C(=O)N[3H])c(NC(=O)CC)c2c([R])c1[R]</smiles><smiles>[R]c1nc2sc3c(=O)n([Al])c(CC#N)nc3c2c([R])c1[R]</smiles>

Scheme 4. Reaction of cyanoacetylpyrazole 1 with thienopyridines 13.

\section{Experimental}

Preparation of 3-[(cyanoacetyl)amino] thieno[2,3-b]pyridine-2-carboxylates 3. General Procedure

A hot solution of $15 \mathrm{mmol}$ of thienopyridine 2 in $25-30 \mathrm{~mL}$ of anhydrous toluene was added dropwise to a solution of $3.00 \mathrm{~g}(18.4 \mathrm{mmol})$ of fr4eshly prepared and dried 1-(cyanoacetyl)-3,5dimethylpyrazole 1 in $10 \mathrm{~mL}$ of anhydrous toluene. The resulting solution was refluxed for $5 \mathrm{~h}$ (TLC); after $\sim 20 \mathrm{~min}$, the product began to precipitate. The mixture was cooled, and the white solid was filtered off, washed with toluene and ethanol, and dried.

Ethyl 3-[(cyanoacetyl)amino]-4,6-dimethylthieno[2,3-b]pyridine-2-carboxylate (3a). Yield 71\%, colorless crystals pourly soluble in acetone and insoluble in boiling ethanol. An analytical sample was obtained by recrystallization from ethanol-acetic acid (1:3). IR spectrum, $v, \mathrm{~cm}^{-1}: 3240 \mathrm{br}(\mathrm{N}-$ $\mathrm{H}), 2250 \mathrm{w}(\mathrm{C} \equiv \mathrm{N}), 1715 \mathrm{~s}$ and $1670 \mathrm{~s}(\mathrm{C}=\mathrm{O}) .{ }^{1} \mathrm{H}$ NMR spectrum, $\delta$, ppm: $1.31 \mathrm{t}\left(3 \mathrm{H}, \mathrm{CH}_{2} \mathrm{CH}_{3},{ }^{3} \mathrm{~J}=6.9\right.$ $\mathrm{Hz}), 2.55 \mathrm{~s}\left(3 \mathrm{H}, \mathrm{CH}_{3}\right), 2.58 \mathrm{~s}\left(3 \mathrm{H}, \mathrm{CH}_{3}\right), 3.96 \mathrm{~s}\left(2 \mathrm{H}, \mathrm{CH}_{2} \mathrm{CN}\right), 4.31 \mathrm{q}\left(2 \mathrm{H}, \mathrm{OCH}_{2},{ }^{3} \mathrm{~J}=6.9 \mathrm{~Hz}\right), 7.19 \mathrm{~s}(1 \mathrm{H}$, $5-\mathrm{H}), 10.35 \mathrm{~s}(1 \mathrm{H}, \mathrm{NH})$. 


\section{References}

1. Dyachenko, V.D.; Tkachev, R.P.; Bityukova, O.S. Chemical properties of cyanoacetanilides and synthesis of biologically active compounds around them. Russ. J. Org. Chem. 2008, 44, 1565.

2. Fadda, A.A.; Bondock, S.; Rabie, R.; Etman, H.A. Cyanoacetamide derivatives as synthons in heterocyclic synthesis. Turk. J. Chem. 2008, 32, 259.

3. Bondock, S.; Tarhoni, A.E.G.; Fadda, A.A.//Arkivoc 2006, part (ix), 113.

4. Fadda, A.A. and Rabie, R. Cyanoacetylation of amines: Recent advances in preparation methods and their synthetic uses in the formation of biologically active compoundsRes. Chem. Intermed. 2016, 42, 771.

5. Shestopalov, A.M.; Shestopalov, A.A.; Rodinovskaya, L.A.//Synthesis 2008, 1.

6. Litvinov, V.P.//Russ. Chem. Rev. 1999, 68, 737.

7. Chigorina, E.A. and Dotsenko, V.V. 1-Cyanoacetyl-3, 5-dimethylpyrazole-effective cyanoacetylating agent and a new building block for the synthesis of heterocyclic compounds. Chem. Heterocycl. Compd. 2012, 48, 1133.

8. Chigorina, E.A. 1-Cyanoacetyl-3, 5-dimethylpyrazole. Synlett 2014, 25, 453.

9. Edraki, N.; Firuzi, O.; Foroumadi, A.; Miri, R.; Madadkar-Sobhani, A.; Khoshneviszadeh, M.; Shafiee, A. Phenylimino-2H-chromen-3-carboxamide derivatives as novel small molecule inhibitors of $\beta$-secretase (BACE1). Bioorg. Med. Chem. 2013, 21, 2396.

10. Hebishy, A.M.; Abdelhamid, I.A.; Elwahy, A.H.//Arkivoc 2018, part (v), 109.

11. Dotsenko, V.V.; Krivokolysko, S.G.; Litvinov, V.P. 1-(cyanoacetyl)-3, 5-dimethylpyrazole as active methylene compound in Hantzsch-type pyridine synthesis: A convenient and highly effective approach to 3, 5-dicyano-4-(het) aryl-6-oxo-1, 4, 5, 6-tetrahydropyridine-2-thiolates. Monatsh. Chem. 2007, 138, 607.

12. Frolov, K.A.; Dotsenko, V.V.; Krivokolysko, S.G. and Litvinov, V.P. Synthesis and properties of triethylammonium 4-aryl (hetaryl)-3, 5-dicyano-6-oxo-1, 4, 5, 6-tetrahydro-pyridine-2-selenolates. Chem. Heterocycl. Compd. 2012, 48, 442.

13. Chackalamannil, S.; Rotella, D.; Ward, S. Comprehensive Medicinal Chemistry III; Elsevier: Amsterdam, The Netherlands, 2017; Volume 1, pp. 124.

14. Buchstaller, H.P.; Siebert, C.D.; Steinmetz, R.; Frank, I.; Berger, M.L.; Gottschlich, R.; Leibrock, J.; Krug, M.; Steinhilber, D.; Noe, C.R. Synthesis of thieno [2, 3-b] pyridinones acting as cytoprotectants and as inhibitors of $[3 \mathrm{H}]$ glycine binding to the N-methyl-D-aspartate (NMDA) receptor. J. Med. Chem. 2006, 49, 864.

15. Alinaghizadeh, F.; Zahedifar, M.; Seifi , M.; Sheibani, H. Cascade synthesis of thieno [2, 3-b] pyridines by using intramolecular cyclization reactions of 3-cyano-2-(organylmethylthio) pyridines. J. Braz. Chem. Soc. 2016, 27, 663.

16. Bakhite, E.A.-G.//Phosphorus Sulfur Silicon Relat. Elem. 2003, 178, 929.

17. Litvinov, V.P.; Dotsenko, V.V.; Krivokolysko, S.G.//Russ. Chem. Bull. Int. Ed. 2005, 54, 864.

18. Litvinov, V.P.; Dotsenko, V.V.; Krivokolysko, S.G. The chemistry of thienopyridines. Adv. Heterocycl. Chem. 2007, 93, 117.

19. Litvinov, V.P.; Dotsenko, V.V.; Krivokolysko, S.G. Khimiya Tienopiridinov i Rodstvennykh Sistem (Chemistry of Thienopyridines and Related Systems); Nauka: Moscow, Russia, 2006; 406 p. (in Russian).

20. El-Sayed, H.A. Heterocyclization of ethyl 3-amino-4, 6-dimethylthieno [2, 3-b] pyridine-2-carboxylate. J. Iran. Chem. Soc. 2014, 11, 131.

Publisher's Note: MDPI stays neutral with regard to jurisdictional claims in published maps and institutional affiliations.

(C) 2020 by the authors. Submitted for possible open access publication under the terms and conditions of the Creative Commons Attribution (CC BY) license (http://creativecommons.org/licenses/by/4.0/). 